\title{
VARIATION OF Pinus caribaea WOOD DENSITY WITH HEIGHT IN TREE AND DISTANCE FROM PITH, IN DIFFERENT SITE CLASSES
}

\author{
N.D. Ruwanpathirana', H.S. Amarasekera ${ }^{2}$ and M.P. de Silva ${ }^{3}$

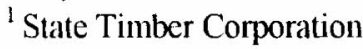 \\ ${ }^{2}$ University of Sri Jayewardenepura \\ ${ }^{3}$ University of Ruhuna
}

\begin{abstract}
Trees were sampled in three stands representing low-growth, medium-growth, and high-growth site classes. Two-centimetre-thick discs were cut, and 2-cmbroad radial strips were cut from each disc in the N-S and E-W directions. These strips were cut into samples $1 \mathrm{~cm}$ wide, numbered from pith to bark. The resulting samples were dried and their density measured. Significantly lesser wood densities were found in the upper parts of the trees and there was a consistent radial density pattern, high at the pith, decresing rapidly to a minimum, and then rising to a constant value which was maintained outwards to the bark. In general the wood from the outer and lower parts of the trees should he strong enough for light to medium construction work. The overall mean density in low growth site was higher compared with other sites, indicating that there is an ssociation between growth rate and wood relative density.
\end{abstract}

\section{Introduction}

The forest cover of Sri Lanka has been diminishing over the last 100 years. The present annual requirement for timber is 17 million $\mathrm{m}^{3}$. and the demand for timber and fuelwood is increasing at $4 \%$ annually(FSMP, 1995). Future supplies from the natural forests will be inadequate to meet the demand, partly because the remaining natural forests have to be managed for conservation purposes. To help overcome the timber shortage, 23,000 ha of pine plantations were established by the Forest Department in the thirty years from 1953 to 1983. as well as other forest plantations, mainly also of exotic species.

Pinus caribaea has a shorter rotation (25 years) than most of the indigenous timber species. Although it has a less durable timber, suggestions have been made to utilize it for joinery purposes (FSMP, 1995). Research on the physical and chemical properties of pine grown in Sri Lanka has been very limited. Pine wood is known to vary in quality from the pith towards the bark. Wood relative density (in carlier literature often referred to as "specific gravity") is a uscful general indicator of comparative wood quality, and the investigation of its variation is particularly useful in considering the most effective utilization of present and future plantations. It has been shown by several workers that some wood characteristics are related 
to the growth rate of the trees and others to inherent characters (Amarasekera, 1991). In this study wood density was investigated in trees from three different site classes, which represent three different growth rates.

\section{Objectives of research}

- To investigate wood density in relation to site class.

- To investigate wood density variation within trees.

\section{Literature review}

The following is an attempt to briefly review the relevant literature.

\section{Site factors}

Site productivity depends mainly on the availability of light and water, temperature, and fertility (Kozlowski, 1971). The proportion of late wood, and the nature of the early wood/late wood boundary seem to be at least partly controlled by the water supply. Harris (1955) showed that the change from early wood to late wood in Pinus sylvestris could be caused by a water shortage at the relevant time.

\section{Wood density}

Wood density is a measure of the amount of cell-wall substance in wood in relation to empty spaces. It has for long been regarded as a useful criterion of wood quality. It can be related to other properties such as physical and working and finishing properties, and can be given an important role in determining the suitability of a timber species for a particular use (Scaramuzzi, 1965). It can be measured by Archimedes' principle: when a body is immersed in a fluid the upthrust on the body is equal to the weight of fluid displaced. If the fluid is water, its density (in $\mathrm{g} / \mathrm{cm}^{3}$ ) can be aproximated to 1 , so the weight of the wood in relation to the weight of fluid displaced is a measure either of its density in these units, or as its "relative density", i.e. relative to that of water, without units.

\section{Wood density variation with height in tree}

Brown (1969), and Hughes (1970) report that in Pinus caribaea wood density decreases with increasing height in the tree. Indeed, Goggans (1961), Nicholls (1986), and Houkal et al. (1988) state that wood density decreases from bottom to top of the tree in most conifers.

\section{Wood density variation from pith to bark}

Wood density varies radially in the tree, with age and distance from the pith. In temperate countries especially, it decreases within the first fifteen rings to a minimum, and then increases with increasing distance from the pith (Brazier, 1967; Elliott, 1960) Andrews \& Plumptre (1973), working with Pinus caribaea from various sites in East Africa, reported that wood density falls slightly at first and rises again, from $0.45 \mathrm{~g} / \mathrm{cm}^{3}$ in ring 2 to 0.59 $\mathrm{g} / \mathrm{cm}^{3}$ in ring 8 , after which the value fluctuates. Observations by Richardson (1961) and 
Mandaltsi (1971) on Pinus nigra revealed patterns of wood density variation in which it is high in the first few rings, then decreases to a minimum, after which it increases, at first rapidly and then more slowly towards the bark.

It may be noted that the radial trend of wood density in ring-porous hardwoods is typically a decrease from the pith outward (Paul, 1963), and that there appears to be no typical wood density trend in diffuse-porous hardwoods.

\section{The influence of growth rate on wood density}

The wood density of the core wood may be strongly influenced by the environment in which the trees are grown. Nevertheless, many workers have found little if any relation between growh rate and wood density (Larson, 1957; Fielding, 1960). Slow rates of growth, particularly in ring-porous hardwoods, are generally associated with reduced wood density. Paul (1963) quotes examples of relatively greater wood density associated with narrow rings at the centre of certain hardwoods. Fast growth may also be associated with reduced wood density in other hardwoods. For example, such an effect was found in young trees of Eucalyptus camaldulensis (Susmell, 1952).

\section{Growth rings}

The total number of cells formed during one growing season and the extent to which they expand will determine the width of that season's growth of wood, referred to as a growth ring (or tree ring). Distinctive "early wood" is believed to be formed during the period of rapid shoot growth and needle formation, when the concentration of auxin in the cambial zone is adequate for the enlargement and differentiation of tracheids in the xylem mother-cell zone (Larson, 1964).

\section{Ring width}

Ring-width variation from pith to bark has been observed in Pinus resinosa (Duff \& Nolan, 1953), Pinus nigra (Richardson, 1961; Mandaltsi, 1971), Picea sitchensis (Dinwoodie, 1963), and Pinus radiata (Nicholls, 1986), among many other softwoods. They found that ring width increases rapidly over the first few rings from the pith, and then decreases towards the bark, until it reaches a constant value. The greatest ring width occurs at (Farrar, 1961) or above (Denne, 1979) the internode with maximum leaf weight.

\section{Wood shrinkage}

Wood shrinkage is a change in any or all of the three dimensions and therefore in volume, resulting from the loss of moisture below the fibre saturation point. Yao (1969) observed that tangential shrinkage decreased with increasing height in the tree, while longitudinal shrinkage increased. In the radial direction, shrinkage decreased from pith to bark. These trends are in line with the patterns of variation in wood density, confirming that shrinkage and density are related. In general, shrinkage seems to be related to factors such as rate of growth, position in the tree, and the presence of reaction wood, as well as to wood density. 


\section{Materials and methods}

\section{Study area}

Study sites for Pinus caribaea were selected from the Nuwara Eliya Forest Range in Nuwara Eliya District, and the Degana Forest Range in Kandy District.

\section{Selection of site classes}

Three site classes were defined from a comparison of data on age, dbh, height, and stocking density in all the Pinus caribaea plantations in Sri Lanka, obtained at the Sri Lanka Forestry Institute in Nuwara Eliya from the FORDATA computerized database. High and mediumgrowth site classes of Pinus caribaea, according to the authors' classification, were selected in the Ramboda Beat in Nuwara Eliya District, and a plantation representing a low-growth site class was chosen in the Digana Range in Kandy District. All three of the selected stands were planted in 1980.

There were remarkable variations in growth rates: the mean values for the low, medium, and high- growth sites respectively were dbh 17,25 , and $35 \mathrm{~cm}$, and height 13,21 , and $24 \mathrm{~m}$. A field check was carried out on the relevant parameters in order to verify the computer information. In addition, the FORDATA information on planting dates was checked with the villagers who had participated in the planting.

\section{Selection of sample trees and dises}

Five trees were felled from each of the three sites. Cross sectional discs, $2 \mathrm{~cm}$ thick, were taken at breast height and at $20,40,60$, and $80 \%$ of the total length of the trees. The four sides of each disc were marked as north, south, east and west.

\section{Measurement of wood density}

Linear sections, $2 \mathrm{~cm}$ wide, were cut across the diameter of every sample disc, from north to south and east to west, avoiding compression wood or distorted grain around the knots. Sample pieces $2 \times 2 \times 1 \mathrm{~cm}$ were cut from these linear sections, labelled according to compass direction and distance from pith.

Oven dry weight at $105^{\circ} \mathrm{C}$ was measured for each sample. The weight of water displaced by the green sample was measured by Archimedes' method. The upthrust on immersion was determined as follows. A beaker containing distilled water was placed on an electronic balance (reading to $0.001 \mathrm{~g}$ ) and the reading was noted. Each sample was immersed to a constant depth by means of a thin stick attached to the stand, and the new reading was taken. The difference in readings gave the weight of water displaced. In all, 2020 samples were measured.

The required data were then calculated from the formula:

Relative density $=$ Ovendry weight of sample $\div$ weight of water displaced

\section{2}




\section{Results}

\section{Variation from pith to bark}

At breast height, wood density increased steadily from pith to bark in the low-growth site. In the medium and high-growth sites it decreased over the first $2-3 \mathrm{~cm}$ from the pith, to a minimum, and then increased gradually towards the bark (Table $1 \&$ figure 1 ).

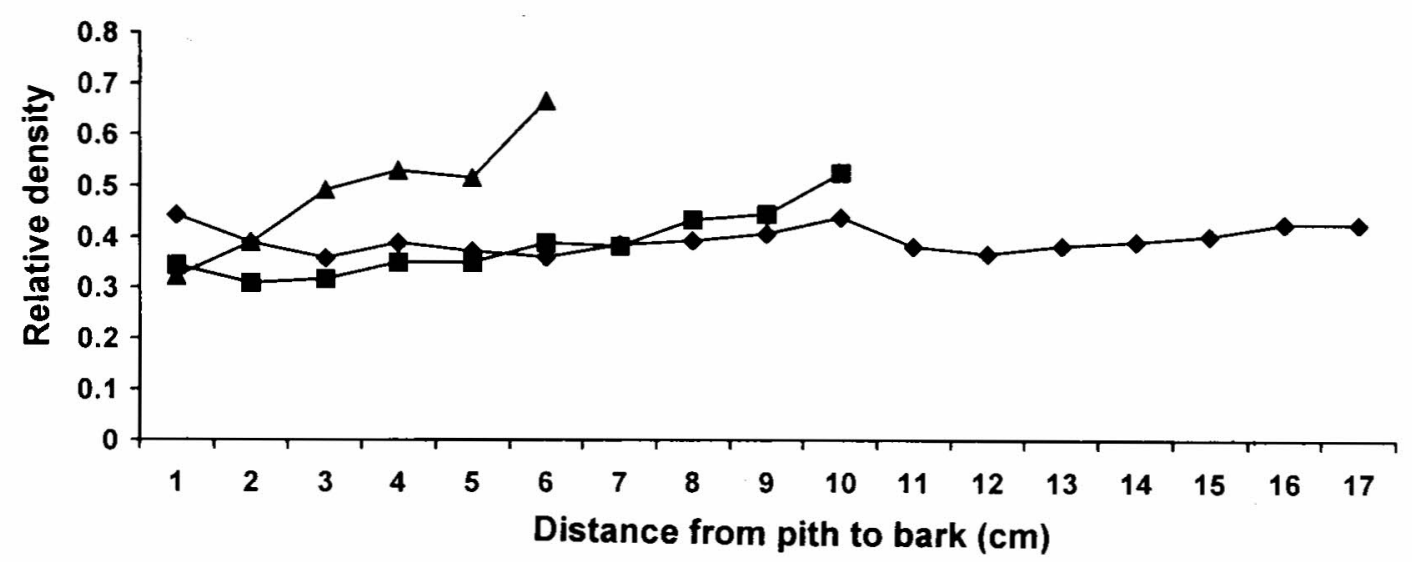

$$
\multimap \text { High-growth site } \rightarrow-\text { Medium-growth site } \rightarrow-\text { Low-growth site }
$$

Figure 1- Wood relative density variation from pith to breast at height

Table 1: Wood relative density in three site classes from pith to bark at breast height

\begin{tabular}{cccc}
\hline $\begin{array}{c}\text { Distance from } \\
\text { pith to bark (cm) }\end{array}$ & $\begin{array}{c}\text { High-growth } \\
\text { site }\end{array}$ & $\begin{array}{c}\text { Medium-growth } \\
\text { site }\end{array}$ & $\begin{array}{c}\text { Low-growth } \\
\text { site }\end{array}$ \\
\hline 1 & 0.442 & 0.345 & 0.322 \\
2 & 0.388 & 0.308 & 0.388 \\
3 & 0.359 & 0.317 & 0.492 \\
4 & 0.388 & 0.350 & 0.528 \\
5 & 0.371 & 0.349 & 0.516 \\
6 & 0.361 & 0.388 & 0.668 \\
7 & 0.385 & 0.382 & \\
8 & 0.394 & 0.435 & \\
9 & 0.406 & 0.446 & \\
10 & 0.438 & 0.527 & \\
11 & 0.382 & & \\
12 & 0.369 & & \\
13 & 0.384 & & \\
14 & 0.394 & & \\
15 & 0.405 & & \\
16 & 0.428 & & \\
17 & 0.428 & & \\
\hline
\end{tabular}


At the $20 \%$ height. density increased significantly from the pith toward the bark in the lowgrowth site. In the medium growth site it decreased slightly over the first $1-2 \mathrm{~cm}$ from pith, and then increased slightly towards the bark. In the high-growth site it decreased to a minimum within $3-5 \mathrm{~cm}$ from the pith, increased slowly up to $8 \mathrm{~cm}$ from the pith, and then maintained a fairly constant value up to the bark (Table 2 ).

Table 2: Wood relative density in three site classes from pith to bark at $20 \%$ height

\begin{tabular}{cccc}
\hline $\begin{array}{c}\text { Distance from pith } \\
\text { to bark }(\mathrm{cm})\end{array}$ & $\begin{array}{c}\text { High-growth } \\
\text { site }\end{array}$ & $\begin{array}{c}\text { Medium-growth } \\
\text { site }\end{array}$ & $\begin{array}{c}\text { Low-growth } \\
\text { site }\end{array}$ \\
\hline 1 & 0.40 & 0.428 & 0.326 \\
2 & 0.412 & 0.362 & 0.367 \\
3 & 0.343 & 0.344 & 0.440 \\
4 & 0.33 & 0.334 & 0.463 \\
5 & 0.298 & 0.331 & 0.513 \\
6 & 0.321 & 0.382 & \\
7 & 0.345 & 0.400 & \\
8 & 0.355 & 0.427 & \\
9 & 0.345 & 0.425 & \\
10 & 0.357 & 0.50 & \\
11 & 0.368 & & \\
12 & 0.387 & & \\
13 & 0.352 & & \\
14 & 0.347 & & \\
15 & 0.339 & & \\
\hline
\end{tabular}

At the 40 \% height, density increased rapidly toward the bark in the low-growth site. In the medium-growth site. it displayed a pattern similar to that of the $20 \%$ height. In the highgrowth site it fluctuated throughout the radial section (Table 3).

Table 3: Wood relative density in three site classes from pith to bark at $40 \%$ height

\begin{tabular}{cccc}
\hline $\begin{array}{c}\text { Distance from pith } \\
\text { to bark (cm) }\end{array}$ & $\begin{array}{c}\text { High-growth } \\
\text { site }\end{array}$ & $\begin{array}{c}\text { Medium-growth } \\
\text { site }\end{array}$ & $\begin{array}{c}\text { Low-growth } \\
\text { site }\end{array}$ \\
\hline 1 & 0.426 & 0.343 & 0.382 \\
2 & 0.403 & 0.325 & 0.394 \\
3 & 0.402 & 0.323 & 0.416 \\
4 & 0.368 & 0.329 & 0.462 \\
5 & 0.384 & 0.346 & \\
6 & 0.375 & 0.362 & \\
7 & 0.377 & 0.395 & \\
8 & 0.396 & 0.43 & \\
9 & 0.359 & 0.406 & \\
10 & 0.406 & & \\
11 & 0.35 & & \\
\hline
\end{tabular}

At the $60 \%$ height, density increased steadily toward the bark in the low-growth site. In the medium-growth site it maintained a fairly constant value from pith to bark. In the high- 
growth site, it decreased to a minimum value within the first $2-4 \mathrm{~cm}$ from the pith, and then increased slightly towards the bark (Table 4).

Table 4: Wood relative density in three site classes from pith to bark at $60 \%$ height

\begin{tabular}{cccc}
\hline $\begin{array}{c}\text { Distance from pith } \\
\text { to bark }(\mathbf{c m})\end{array}$ & $\begin{array}{c}\text { High-growth } \\
\text { site }\end{array}$ & $\begin{array}{c}\text { Medium-growth } \\
\text { site }\end{array}$ & $\begin{array}{c}\text { Low-growth } \\
\text { site }\end{array}$ \\
\hline 1 & 0.423 & 0.339 & 0.35 \\
2 & 0.362 & 0.343 & 0.386 \\
3 & 0.330 & 0.359 & 0.477 \\
4 & 0.327 & 0.340 & \\
5 & 0.332 & 0.330 & \\
6 & 0.347 & 0.384 & \\
7 & 0.370 & & \\
8 & 0.369 & & \\
9 & 0.401 & & \\
\hline
\end{tabular}

At the $80 \%$ height, density increased slightly towards the bark in all the three sites. High, medium and low values were observed in all the cross sections, in the low-growth site, highgrowth site, and medium-growth sites respectively (Table 5).

Table 5: Wood relative density in three site classes from pith to bark at $80 \%$ height

\begin{tabular}{cccc}
\hline $\begin{array}{c}\text { Distance from pith } \\
\text { to bark (cm) }\end{array}$ & $\begin{array}{c}\text { High-growth } \\
\text { site }\end{array}$ & $\begin{array}{c}\text { Medium-growth } \\
\text { site }\end{array}$ & $\begin{array}{c}\text { Low-growth } \\
\text { site }\end{array}$ \\
\hline I & 0.324 & 0.3 & 0.398 \\
2 & 0.33 & 0.3 & 0.41 \\
3 & 0.33 & 0.3 & \\
4 & 0.333 & 0.33 & \\
5 & 0.326 & & \\
6 & 0.340 & & \\
\hline
\end{tabular}

\section{Variation from bottom to top}

The mean wood density of the discs decreased at increasing heights in the trees, except at the $80 \%$ height in the low-growth site and the $40 \%$ height of the high-growth site.

The mean wood relative density over all three sites at the different height levels was follows: breast height, $0.41 ; 20 \%$ height, $0.38 ; 40 \%$ height, $0.39 ; 60 \%$ height, $0.36 ; 80 \%$ height, 0.34 These differences were significant at the 0.05 level.

The mean whole-stem weighted relative densities in the low, medium and high-growth sites are shown in Table 6. The differences between the sites are significant at the 0.05 level. Differences between medium and high growth sites are not significant $(p \leq 0.05)$, but low growth site has significantly higher relative density compared with other sites. 
Table 6: Mean whole stem relative density in the low, medium and high growth sites

\begin{tabular}{ll}
\hline Site & Relative density \\
\hline low & $0.41 \mathrm{a}$ \\
medium & $0.36 \mathrm{~b}$ \\
high & $0.37 \mathrm{~b}$ \\
\hline
\end{tabular}

Values with the same letters do not significantly different at $p \leq 0.05$ level according to Turky test

\section{Conclusions}

The palten of radial variation of wood density was broadly similar at all height levels on all sites: high near the pith, falling to a minimum within $3-5 \mathrm{~cm}$. then increasing steadily and rapidly towards the bark. The outer wood of the bottom pan of the trees on all the sites is suitable for light to medium construction. This study indicates that there is an association between growth rate and the wood density Wood relative density of low growth site was higher compared to other sites.

\section{References}

Amarasckara. H.S (1991). Juvenile wood formation in relation to crown size in (orsican pine. Ph.D Thesis. Universtily of wales (Bangor): 147

Andrew. I.A. and R A Plumptre (1973) An Investigation of variation in wood density and growth of Pims carihaea var. hondurensis grown on various sites in east ifrica. Commonwealth for . Inst, oxford

Brazier. J.D. (1967). A study of variation in wood characteristics in Sitka spruce. Forestry 40. $117-128$.

Brown. G.A. (1969). i biometrics analysis of some variation in the anatomv of voung Pinus carihaea Ifor. Ph.D. Thesis, Oxford Universily.

Denne. M P (1979) Wood structure and production within the trunk and branches of Picea sitchensis in relation to canopy formation. ('anadian. Journal of forest Research, 9: $406-427$

Dinwoodic. J M (1963) Variation in tracied length in Picea sitchensis carr Forest Products Resereh Special repert Vo: 16. Dept of scientific and Industrial Rescarch, London: $55 \mathrm{pp}$

Duff. G.H. and Nolan. N.J. (1953). Growth morphogenesis in the Canadian forest species. The controls of cambial and apical activity in Pimes resinosa Ait. Canadiam formmal of Botom 31, 471-513.

Elliott. G K $(196(1)$ The distribution of tracheid length in a Single Stem of sitka spruce $J$ Inst. wood Sici $5.38-47$

Farrar. J L $(1961)$ Longitudinal Variation in the thickness of anmual ring. Forestry (hronicle 37: $323-30$

Ficldng. J.M. (1960). Branching and flowering characteristics of Monterey pine (Pinus radicta). Bulletin of the Timber Bureau of Australia No.37 (Reviewed by Elliott. $197(0)$. 
FSMP (1995) Foretry Sector Master Plan, Ministry of Agriculture, Land and Forestry, Sri Lanka

Goggans. I.F (1961) The interplay of enviromment and heredity as factors controlling wood properties in conifers with special emphasis on their effects on specific graviry

Harris, E.M.H. (1955). The effect of rainfall on the latewood of Scots pine and other conifers in East Anglia. Forestry 28 (2) 136-140.

Houkal. D.. Ponce. E and Villalobes, D (1988) Within-tree variation of specific gravity in ocote Pine. Turrialba 38(2), 97-104. Quoted from Forest Products Abstracts 12(5):758

Hughes. I F (1970) Preliminary investigations of some structural Features and properties of wood of Pinus caribaea from Hondurus. Commth for: Rev. 49(4) No: 1422: 336355

Kozlowski. T.T (1971) Growth and development of trees. Vol II. Combial growth, root growth and reproduction growth. Academic Press: New York: $514 \mathrm{pp}$

Larson. P.R. (1957). Effect of environment on the percentage of summenwood and density of slash pine. Yale University School of Forestry Bulletin No. 63.

Larson. P.R. (1964). Some indirect effects of environment on wood formation. In The formation of wood in forest trees. Ed. Zimmerman. Pp. 345-365. Academic Press.

Mandaltsi. V (1991) A study of some Structural Features and properties of the wood of Pinus nigra. Arnold M. Sc Thesis (Univ. of Oxford) pp 236-255

Nicholls, J.W.P (1986) Within-tree variation in wood characteristics of Pinus radiatc D. Don Australian Forest Research 16(4): 313-35

Paul. B.H. (1963). The application of silviculture in controlling the density of wood. Teechnical Bulletin, USDA. No. 1288.

Richardson, S.D. (1961). A biological basis for sampling in studies of wood properties. TAPPI 44 (3) 17()-173.

Scaramuzzi, G. (1965). The relationship of fibre wall thickness. fibre diameter and percentage of summer-wood (latewood) to density. Meeting IUFRO Section +1 , Vol.2, Melboume.

Susmell, L. (1952). Correlation between annual rings, proportion of late wood, trachcids and density of Douglas fir wood. Italia Foreste Monte 30-45.

Yao. J. (1969). Shrinkage of second growth southern yellow pine. Wood Science and Technologv 3, 25-29. 